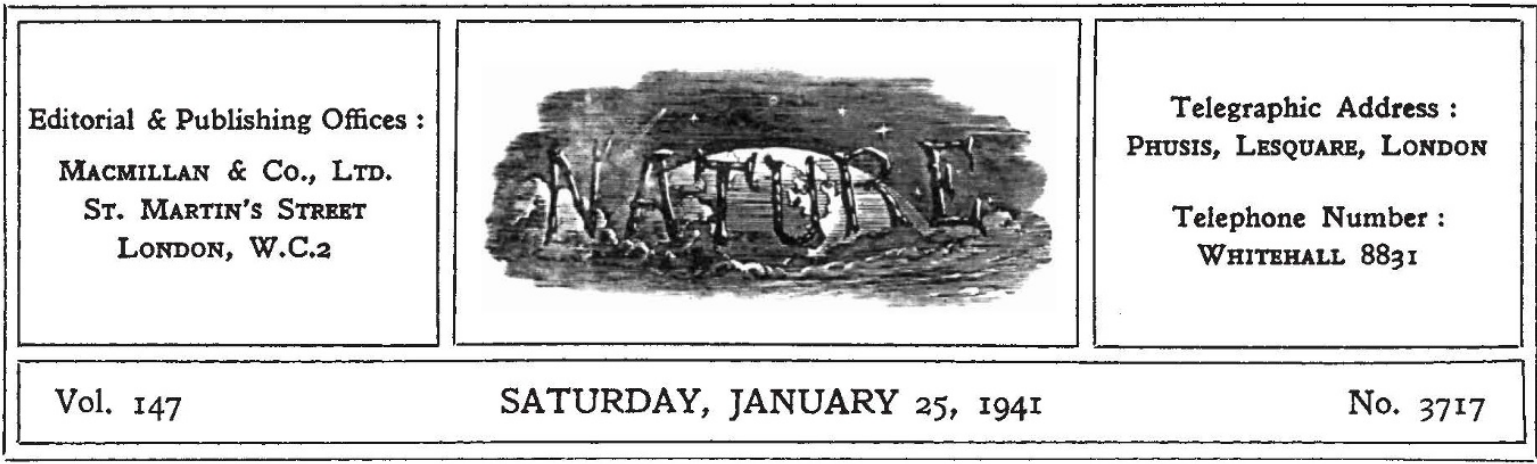

\title{
LEADERSHIP IN CIVIL DEFENCE
}

IN the searching ordeals of bomb and fire through 1 which one after another of our great cities have passed, the fortitude and courage of their citizens has time and again overshadowed material destruction. Few can pass along those stricken streets without being inspired by the capacity of men and women to rise above discomfort, sorrow and heavy loss, or without viewing in the splendour of the human spirit revealed alike in the work of civil defence, or of caring for the homeless and suffering, an earnest of our powers to build better when the opportunity comes. The unconquerable spirit revealed in the address of the City Architect of Coventry before the Royal Society of Arts early in December attests that the opportunities are already realized, and that out of the present evil, as from a forest fire, may come greater riches and beauty.

The patient heroism and stedfast service which so many eitizens have displayed in these days of trial should not lead us to imagine that all is well, even in the human element. The reports of the Horder Committee show how much still remains to be done for the safeguarding of health in public shelters, and in the repair of ravages in the welfare services. Education itself is a victim of air warfare which even yet has shown no sign of approaching convalescence. The extension of the principle of compulsory fire watching is itself a reminder of a field in which there has been the gravest dereliction of duty both by corporations and by individuals.

The response to Mr. Herbert Morrison's appeal for the immediate formation of fire-bomb fighting parties in business and residential districts shows that the ordinary citizen is now fully alive to this particular danger and is eager to play his part. It may be true that in Great Britain we must have experience before we do our best. Even the stern teaching of the school of fire precautions in London was ignored by many until the lesson was learned in their own hard school. That the lesson has been well learnt has since been shown by recent experience in Cardiff, Bristol and elsewhere.

In spite of this national failing, it is not with the individual citizen that the chief weakness or danger lies, whether in this matter of fire-fighting or other questions. That lies rather in the failure of the Government to use to the full the wide powers with which it has been entrusted, and in the absence of real leadership which has charaeterized both Government policy and local authorities in various fields. Few as may be those who seek to evade their responsibilities and duties, unless the Government is prepared to deal with the offenders in such matters as fire-fighting, the training of labour, the evasion of rationing, neglect of cultivation, to indicate only a few widely differing fields, the defection of the few may involve the whole community in severe suffering and hardship.

If, therefore, the amended Fire Watchers Order is to prove adequate, there must be no failure to enforce it by stern penalties where necessary. Weakness at this point may invalidate the efforts of the many and defeat the purpose of the whole organization for dealing promptly and efficiently with the menace. It is always at its weakest link that the chain is tested. Evidence that the Government was determined to act vigorously in this matter where required and prepared to institute the necessary inspectorate to collect any evidence of neglect would have a moral effect reaching far beyond the field of fire-fighting. 
No less important, however, is the question of leadership or direction. Unless that is wise and effective, the fullest use cannot be made of the zeal and courage and heroism of the individual, either as the private citizen or as a member of the civil defence services. There is lamentable evidence that damage has been done which could have been prevented because fires were not tackled rightly at the start, and because no one in the area had been made responsible for judging what kind of a fire it was, its peculiar dangers, and for seeing that the proper number of machines was there. In fire-fighting no less than in other warfare, there must be efficient command.

It is no fault of the Auxiliary Fire Service that its firemen are not strategists and that its own officers lack the experience of the long-trained fire expert. Something must be done to supply the necessary direction to this valuable and immensely willing force. Adoption by all cities and towns of the London practice, according to which all fires in a defined area are watched over by a senior officer in control of fire, has much to commend it. This officer patrols round them, directing operations, giving advice, and is expert enough to know what assistance may be needed. If junior officers accompanied him, this strategist might even run a school for strategy.

A major purpose of the Fire Watchers Order is to increase the efficiency of the fire services; setting them free to concentrate their energies, by the systematic prevention of unnecessary fires. It should be a first duty of the new fire prevention executive to increase that efficiency from the other side by strengthening command and strategy. Nor is it only in the field of strategy that command needs strengthening. The neglect of the firemen on duty has been a most lamentable feature of more than one of our great cities in their recent ordeals. Admirable arrangements for caring for the homeless by the provision of accommodation and meals have existed side by side with a scandalous neglect to provide rest or food for the men continuously engaged for long hours in bringing the fires under control.

There is, indeed, unmistakable evidence that some fire organizations and the authorities controlling them have yet to learn what is really implied by Napoleon's dictum that an army marches on its stomach. Neglect of the physical welfare of the auxiliary firemen may be as detrimental to the efficiency of the fire-fighting services as the absence of strategy, and is an equally damning indictment of the command. What is more, it is deeply resented by the many citizens to whom it has been obvious in recent weeks, and who to their honour have sought by private generosity to repair official neglect.

These are among some of the matters to which Mr. W. S. Morrison and Sir John Greenly may rightly be expected to give their attention when they have selected the personnel of the new fire prevention executive, if there is not in the meantime a speedy improvement in the situation. Important as they may be, they are, however, only mentioned here as illustrations of the damage which defective command or inefficient administration may do to the national effort. Administrators who are unequal to their task must be removed from office as ruthlessly and unhesitatingly as generals or admirals or air-marshals whose powers have been overtaxed by command.

It will be well, therefore, if deficiencies in direc. tion and command which have been revealed in our civil defence services by recent events stimulate further attention to this vital matter of leadership. The consequences which can flow from defective leadership, whether through lack of vision or organizing capacity, or administrative inefficiency, are too far-reaching to be disregarded. They may equally impede the smooth supply of munitions for the forces, raw materials for our factories or provisions for the civil population, impair the efficiency of a civil defence body such as the Auxiliary Fire Service, or deal fatal blows at the morale of the nation, upon which the sustenance of our war effort finally depends.

There is urgent need for searching scrutiny from above of almost every side of civil administration and leadership. Some, indeed, have already received attention from the Select Committee on National Expenditure, and the wide range of the admirable reports which that Committee has already issued suggests that such a further survey of civil administration and command might well come within its orbit. It may at least be hoped that the Government will speedily implement such an inquiry, whether through the Select Committee or some and other preferred means, and take the immediate and appropriate action on its findings. Only so can we ensure that parochialism, departmentalism and administrative incapacity no longer offer the barrier to our national effort which they have long offered in local government and to the development of regionalism, and which, if unchecked, they will assuredly offer to post-War reconstruction. 